\title{
Evangelicalising Black Pentecostalism: The Mechanics of Change at the Apostolic Faith Mission Sharpeville Congregation (1981-1985)
}

Thabang Richard Mofokeng

http://orcid.org/0000-0002-5114-4886

North-West University

trmofokeng@gmail.com

\section{Abstract}

A recent study argues that black Pentecostalism in the Apostolic Faith Mission (AFM) of South Africa became evangelicalised through the agency of white missionaries. The study was national in scope and drew from archival as well as secondary sources. This article, on the other hand, seeks to contribute to an understanding of how evangelicalisation worked in a concrete situation of a specific congregation by analysing oral historical and archival material related to this process in the AFM Sharpeville congregation, between 1981 and 1985. The article answers the following question: How did evangelicalisation of black Pentecostalism happen at the congregational level of the AFM? The findings suggest that evangelicalisation at the level of the congregation happened through the appointment of (an) evangelical pastor(s), the use of evangelistic and revival campaigns, as well as pastoral discretion in deciding what to relent to, what to refrain from, and what to emphasise in their engagement with the congregation.

Keywords: Apostolic Faith Mission; black Pentecostalism; evangelicalisation; oral history; Sharpeville; Zionism

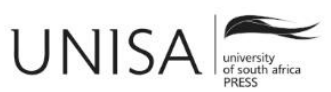




\section{Introduction}

The Apostolic Faith Mission (AFM) of South Africa is a denomination that was divided according to race until 1996. Anderson and Otwang (1993, 6-7) portray the pre-unity black section of this denomination as an evangelical Pentecostal church, whose members' attitudes were antagonistic towards indigenously founded Zionist churches. ${ }^{1}$ Anderson $(2006,121)$ identifies missionaries as the origin of negative black Pentecostal attitude towards Zionism. ${ }^{2}$ Missionaries considered Zionism a deviation from Christianity, especially Pentecostalism (Bond 1974, 14). Using the idea of deviation, Mofokeng $(2018,71)$ locates Anderson in the same camp as the missionaries he writes about, for he too views Zionism as a deviation from Pentecostalism - albeit a positive one - as it led to the contextualisation of Christianity into the African milieu (Anderson 2004, 108). Mofokeng $(2018,81)$ agrees with Anderson about Zionist contextualisation of Christianity and includes black Pentecostals of the AFM as having been participants in the process $(2018,78)$. He also argues that it was black Pentecostals, and not the Zionists, who deviated $(2018,72)$. He points to a process of evangelicalisation that climaxed in the 1970 s as constituting that deviation $(2018,117){ }^{3}$

Although Mofokeng (2018, 100-104) outlines how the missionaries carried out the evangelicalisation project at the macro level, he has not given attention to how evangelicalisation occurred and what its effects were at the congregation level. In this article, the AFM congregation in Sharpeville is made a case study of the process of evangelicalisation, covering the first five years of Pastor Paulus Mtsweni's tenure (1981-1991), a period during which there was accelerated change in this congregation. The following question drives this research: How did the evangelicalisation of black Pentecostalism happen at the congregational level in the AFM? Two factors influenced the choice for this congregation, namely: its history as a Zionist-like Pentecostal congregation, which later embraced evangelical Pentecostalism; and its accessibility to the researcher. Following hereafter is a discussion of the methodology adopted in this article. This is followed by discussions of the brief pastoral history of the AFM congregation in Sharpeville; the existence of Zionist-like Pentecostalism at Sharpeville; the pressure to abandon this form of Pentecostalism; the victory of the evangelical faction; a pastoral perspective on evangelicalisation of a congregation; and in the conclusion, the mechanics of overcoming resistance.

1 The terms "Zionist," "Zionism" and "Zionist-like" apply broadly to the spirituality, theology and phenomena associated with charismatic churches that seceded from the AFM in its first decade, as well as those that were established from the 1930s (see Mofokeng and Madise 2019, 3-4).

2 In Anderson and Otwang (1993, 2), "missionary" refers exclusively to white ministers who were involved in the gospel work among nationalities other than their own. The same usage is applicable in this article.

3 Evangelicalisation refers to a process curated by missionaries in which a Pentecostalism that was oriented towards African traditional culture and the Old Testament shifted towards the New Testament and Western culture (see Mofokeng and Madise 2019, 10-12) - from spirit-centredness to Christcentredness (Larbi 2002, 147) and an individualised concept of salvation (Mathole 2005, 196). 


\section{Methodology}

Little written information exists on the AFM congregation in Sharpeville. The situation of this congregation is not unique, as Burger and $\mathrm{Nel}(2008,220)$ acknowledge the dearth of written information on black Pentecostal personalities and congregations, a problem to which they see oral history as a remedy. Oral history is both a research method and a product that draws from the memories of participants and/or observers of events of interest to the historian. As a research method, oral history is engaging in an audio or video-recorded conversation between inquiring and narrating participants, which revolves around the narrator's experiences or observations of a particular event or events within a specific period (Oelofse and Du Bruyn 2004, 153). The recording of this conversation is the first step towards becoming an oral history product. Other steps include transcription, summarising and/or indexing the content and submission to a public repository such as the library or the archives.

Due to the acknowledged lack of written information on the AFM congregation in Sharpeville, this article relies on oral history and archival material as primary sources, as well as applicable secondary sources. The archival material comes from the AFM archives in Auckland Park and is mainly minutes of various councils and conferences. This archival material provides background and context within which to understand and confirm aspects of the oral history of the Sharpeville congregation. A minute book of the Sharpeville church board, covering the period 1983 to 1992, was received from a former board secretary. Most secondary source data derive from Anderson (2000; 2002; 2004; 2006) and Mofokeng (2018). The oral history data derive from seven transcripts of interviews that the researcher conducted in 2008 and 2009. The participants interviewed in that oral history project were required to have observed or participated in the changes in the beliefs and practices black members of the AFM underwent in the late 1970s. Of the seven transcripts, four provide a lay perspective on the subject, while three represent a ministerial perspective. The ministerial perspective divides into one focused on a congregation (in the Free State Province where the participant pastored a Zionist-like congregation) and another on a broad view of a minister involved in itinerant evangelistic and revivalist ministry on behalf of the AFM.

A snow-ball sampling method was used and the necessary ethical requirements pertaining to consent to, and withdrawal from participation as well as permission to use interview data in publications were observed (Strydom 2011, 113-119; Strydom and Delport 2011, 393-394). The transcripts of the minister of a Zionist-like congregation were included because of the desire to gain pastoral insight into how evangelicalisation occurred in a congregation. Excluding these transcripts would have deprived this paper of such insight because the researcher missed an opportunity to interview the pastor who was involved in the changes at the AFM in Sharpeville before he passed away. The other minister's transcript had a minor, yet important, contribution in confirming some information raised in transcripts of lay participants. All transcripts were analysed for details relevant to providing an adequate answer to the question posed above. The 
emerging details were compared across transcripts to confirm and explain emerging data in the quest to ascertain its trustworthiness. Finally, this oral history data set was interwoven with documentary data from secondary sources to create a chronologically arranged thematic account of the evangelicalisation of an AFM congregation in the process of answering the research question.

\section{A Brief Pastoral History of the AFM Congregation in Sharpeville}

The history of the AFM Sharpeville congregation starts with its founder, Galelekile James Tyobeka. He was born in 1892, in what is now the Eastern Cape Province. Although living members of his family could not explain why he came into the interior, it may be surmised that it was in search of work as the goldfields of the Free State attracted men from all over South Africa and beyond. He was ordained into the ministry of the AFM as an evangelist in 1923 (AFM Native Conference [AFM-NC] 1923). According to the policy governing the black AFM then, an evangelist was licensed to do the same tasks as an elder with the difference that the former served under the latter, and had an itinerant ministry, whereas the latter was in charge of the congregation and served under a district overseer (AFM-NC 1915). Occasionally, an evangelist could be left in charge of a congregation. Where such a situation existed, the evangelist concerned would account to the district overseer, who was typically a white missionary.

Evangelist Tyobeka was associated with Parys in the year of his ordination and with Vereeniging by 1930 (AFM-NC 1923; 1930). Before coming to Sharpeville, oral history testimony makes him a resident of Top Location, which was a shanty town just to the north of Vereeniging central business district (Interview, Mathole 2008, 10). Sharpeville was built on Leeukuil farm to the west of Vereeniging and near Leeukuil Dam in 1943. ${ }^{4}$ By 1967, its population was 42500 (Hatane 2002, 45), only declining by a thousand over four decades (Slabbert 2004, 62). Its inhabitants were drawn strictly from Top Location because the town council wanted to drain this location of its population before demolishing it for being in a white-designated area which became targeted for industrial development (Chaskalson 1986, 4, 9; Lebusa 2009, 95-96).

In Sharpeville, Evangelist Tyobeka conducted church services at his residence in the Putswastene section, house number 968 Mphaphathi Avenue, before the congregation took possession of the new facility dedicated for use on 10 December 1960 (Interview,

4 Although Sharpeville rose to prominence with the 21 March 1960 police massacre of protestors, from its inception until the beginning of the 1980s, it was marked by political inactivity (Lebusa 2009, 96, 134-135). Two main reasons for the inactivity were, according to Jeffrey (1991, 58, 178-179), Lodge $(1984,132)$ and Vally $(2010,58-59)$, that relocation to Sharpeville was an upgrade in living conditions of most former Top Location residents; and by design and execution, the township was built for surveillance and ease of containment of any disquiet from the local population. However, the postmassacre political inactivity was not a peculiarity of Sharpeville alone, but the entire black population of South Africa (Jeffrey 1991, 176-177). Political reawakening came in the 1970s, inspired by the activities of the Black Consciousness Movement. 
Mathole 2008, 6). ${ }^{5}$ This new facility was at stand 8893 in the Phelandaba section and constituted of a church hall that could take 120 persons and standalone toilets, which initially used buckets as was the rest of the township at that time. The manse, one of the only three in the AFM across the Vaal townships, was built in the early 1980s with funds provided by the Sharpeville congregation assisted by the white AFM in Vereeniging (Interview, Tshabalala 2008b, 25). These facilities still serve the Sharpeville congregation today, albeit new facilities are being constructed. According to Tshabalala (Interview, 2008a, 4), under the pastorate of Evangelist Tyobeka, the Sharpeville congregation drew members from a vast area, which included Meyerton to the north of Vereeniging, Refengkgotso to the east, Boipatong to the west of Sharpeville, Bophelong and the farms to the south-west of Vanderbijlpark, up to Parys. The geographic span of Evangelist Tyobeka's ministry suggests that he might have continued serving his rural congregants in Parys from his Sharpeville base. The areas which constituted the Sharpeville circuit were manned by preachers who all served under Evangelist Tyobeka. He passed away in 1971, at the age of 79 .

Pastor Simon Mlotsha ${ }^{6}$ succeeded Evangelist Tyobeka (Interview, Mathole 2008, 3) and retired from ministry in 1980 (AFM in Africa Executive Council 1980). Pastor Paulus Mtsweni assumed the leadership of the Sharpeville congregation from 1981 until 1991, when he too retired (AFM Sharpeville Church Board 1991). His path to ministry came when he was appointed together with others, as mine chaplains, and given the status of full-time elders in 1975 (AFM in Africa Executive Council 1975b). Pastor Mtsweni came from Kwa-Thema, Springs, where his brother, Matthew Mtsweni, was the resident pastor for many years until he was called to the Bible College in Soshanguve (AFM in Africa Executive Council 1975a; 1975b). Matthew Mtsweni was a long-standing member of the Executive Council and one of the only two black members to be appointed in 1962 (AFM Bantu Executive Committee [BEC] 1962). Matthew's son, Adam Mtsweni, joined Reinhard Bonnke's Christ for All Nations (CFAN) evangelistic ministry after its establishment in 1975 (Khathide 2010, 80; Steele 1988). Thus, Pastor Mtsweni came from a family associated with evangelical Pentecostalism. His decadelong tenure in Sharpeville coincided with unprecedented changes in the self-

5 According to Chaskalson (1986, 11), the Vereeniging municipality had made allocation for nine church sites in Sharpeville. Some of the early occupants of these sites were the African Methodist Episcopal Church, Anglican Church, Apostolic Faith Mission, Assemblies of God (AOG), Dutch Reformed Church, Evangelical Lutheran, Methodist Church, Presbyterian, Roman Catholic Church, the St John's Apostolic Faith Mission (St John's AFM). Of the Pentecostal tradition, only the AFM and AOG existed. The Full Gospel Church of God opened a branch in Sharpeville in 1987 (Lebusa 2009, 312). The AOG was founded by Reverend Phillip Molefe at Top Location in 1952 (Lebusa 2009, 306). Then, it relocated to Sharpeville in 1954. Besides these two, the St John AFM also relocated from Top Location to Sharpeville and was allocated a site next to AOG in Phomolong section. Both the AFM congregation and St John AFM shared in a common Zionist-like Pentecostal form. However, as part of the independent church movement, St John continued to adhere to the Zionist form when the AFM transformed into an evangelical Pentecostal movement (Mofokeng and Madise 2019, 4).

6 Pastor Mlotsha's name is variously spelled in the minutes as Mloja, Mlothsa, Mlotya (AFMA Executive Council March 1971; 1975a; March 1980). 
understanding and practices of this congregation, which precipitated an exodus of members to Zion-Apostolic denominations that had seceded from the AFM earlier (Interviews: Mathole 2008, 5; Seritili 2008; Tshabalala 2008a, 19).

Upon the retirement of Pastor Mtsweni in 1991, Samuel Otwang became the presiding pastor. However, his tenure was short-lived as he left to study in the United States of America in 1996. David Nthoroane became the new pastor in 1997, only to leave in 1998. He was succeeded by Thabang Mofokeng in 2000 (AFM Sharpeville Church Board 1999), an unmarried young man, then recently graduated from the denominational seminary. For this congregation, having an unmarried young man for a pastor was a break with the past as all the previous pastors were married. Pastors Tyobeka, Mlotsha and Mtsweni were old when they led this congregation. Pastors Otwang and Nthoroane were relatively younger, but older than Mofokeng when they assumed leadership at AFM Sharpeville.

\section{Zionist-like Pentecostalism at the AFM in Sharpeville}

Mofokeng and Madise (2019, 3-4) describe Zionist-like Pentecostalism in the AFM as having been characterised by the wearing of church uniform, the use of water for healing in addition to the laying of hands, bearded men, a general orientation towards the Old Testament, and observance of certain African traditional rituals. The description was derived from a document study of archival material and some secondary sources (Mofokeng and Madise 2019,2). Oral history interviews conducted in Sharpeville confirm the use of uniforms and the observance of African traditional rituals. Women members wore black shoes, black skirts, blue blouses with a white bib, and a white hat (Interviews: Mathole 2008, 7; Seritili 2008; Tshabalala 2008b, 26). Men put on white dust-coats on top of black suits, while pastors included clergy collars (Interviews: Mathole 2008, 7; Tshabalala 2008a, 13). However, Seritili (Interview, 2008) recalls no uniforms for men, including pastors, whereas Mathole (Interview, 2008, 7) and Tshabalala (Interview, 2008b, 26) specifically mention Pastors Tyobeka and Mlotsha wearing collars. The worship service usually took an hour, contrary to today's typical three-hour long service in black congregations in the AFM. Only hymns were sung and they were accompanied by the clapping of hands. There were no music instruments and public address systems that now characterise almost all AFM congregations. Only vernacular was used in church, unlike the current dominance of English phrases and songs in evangelical Pentecostalism (Interview, Seritili 2008). Observance of Ascension Day and Paseka ("Passover") celebrations included a whole night Saturday service before the resurrection Sunday, which was part of the practices of this congregation (Interview, Mathole 2008, 9). Rites like tombstone unveilings and other practices, which the AFM associated with the ancestral cult, were also observed (Interviews: Mathole 2008, 5; Tshabalala 2008a, 15). In the words of Mathole (Interview, 2008, 10), discounting the white people who would occasionally visit Pastor Tyobeka's services, the AFM congregation in Sharpeville was like any other Zion-Apostolic church. 


\section{The Pressure to Abandon Zionist-like Pentecostalism}

By the 1970s, some pastors and congregations no longer subscribed to the older Zionistlike culture because the project of transforming black Pentecostalism had been running for several decades already (Mofokeng and Madise 2019, 5). These pastors and their congregations enjoyed the support of the evangelicalising institutional machinery, as district and national conferences were organised in favour of the evangelicalising project. Bonnke's CFAN had evening sessions allocated to evangelistic campaigns in which conference attendees were the primary audience. Conferences, revivals and evangelistic campaigns provided platforms to propagate evangelical Pentecostalism through preaching, testimonies, youth choirs and the denouncing of Zionist-like Pentecostalism. Evangelical Pentecostal congregations seemed to attract large numbers of young people who constituted vibrant choirs, much to the envy of some congregations holding on to a Zionist-like culture - the Sharpeville congregation belonged to the latter (Interview, Tshabalala 2008a, 18). These Zionist-like congregations had more elderly people than youth and wished that their youth could be just as active. However, the triumphalist attitudes associated with those said to be born again and the bravado that went with their testimonies of salvation, were a source of conflict and broken relationships both at conferences and local congregations (Interviews: Malete 2008, 7; Mofokeng 2009, 20). In some districts, traditionally inclined congregations withdrew from conferences dominated by youthful evangelicals who had the backing of the denominational leaders (Interview, Mofokeng 2009, 22).

The Sharpeville congregation was one of the last congregations, in the East Rand district, to give up the practices associated with Zionist-like Pentecostalism (Interview, Seritili 2008). The more conspicuous practice was the wearing of uniforms, which the missionary leaders of the black AFM had been fighting since 1929 (AFM-NC 1929). Pastor Mlotsha's wife reportedly complained about the pressure she received from other already converted ministers' wives at conferences and meetings (Interview, Seritili 2008). Not only was this pressure exerted on pastors and their wives from conservative congregations, but even members were also subjected to the same, according to Seritili (Interview, 2008). The pressure to embrace evangelicalism was mostly resisted by members in the Bophelong branch of the Sharpeville congregation. These members vehemently held on to their uniforms and exerted a counter pressure to the one they felt in conferences. According to Seritili (Interview, 2008), the other members who wanted to abandon uniforms felt intimidated.

The struggle for and against uniforms in the AFM waged since 1929, revolving around contested meanings of being Christian and the maintenance of Christian identity. For black AFM Pentecostals of the Zionist-like era, the entry into, and continuance in the Christian life were approached sacramentally through baptism, robing, and the celebration of communion (Anderson 2000, 48; Interviews: Mofokeng 2009, 10-12; Tshabalala 2008b, 29). The baptised individuals were robed and invited into celebrating communion. The uniforms signified their new identity as fellow members of Christ's 
church and witnesses thereto outside the church community. The uniforms further signified commitment to the new life of Christian discipline. Mofokeng $(2018,79)$ also points out a socio-economic aspect to the uniforms, as masking the inequalities between the poor and the better-off. However, evangelicalist missionaries and their black followers showed no sympathy for the above understanding, as seen through the recollection of the stance of Pastor Mtsweni towards uniforms. Mathole (Interview, 2008, 4) represents Pastor Mtsweni's stance as rejecting the sacramental value of uniforms in the quote below:

Hobane re ntse re le jinifomo jwale ka ha ntse re tenne tje. Ha e etse niks ebile ha e bolele niks le pela Modimo hobane one thing [for] sure, ha le hlokahala le e siya hae mo, ha e tsamaye le lona, ha le yo e apara le koo le yang. [Loose English translation: Because our own clothes are themselves uniforms. Uniforms do nothing and mean nothing before God. Certainly, you will leave these uniforms when you die. You will not wear them where you are going (beyond the grave).]

In the above representation, ordinary clothes are juxtaposed with church uniforms in a manner that appropriates the special value of the latter. At the same time, uniforms are demeaned of transcendent significance. Tshabalala (Interview, 2008a, 13) concurs with the above desacralisation of the uniforms and demonstrates a new understanding characteristic of evangelical Pentecostalism. In this new understanding, uniforms become "an expensive way of securing God's attention" and "a waste of time"; as "Christianity is internal." The denominational leaders had concluded about the irreconcilability of sacramentalism, represented by Zionist-like Pentecostalism, with their evangelical conception of the Pentecostal faith.

\section{Evangelicalising Forces Win the Contest over the Sharpeville Congregation}

A well-regarded sign of evangelicalism, at least to the members of the AFM congregation in Sharpeville, was the forsaking of uniforms and making verbal declarations of personal salvation. Within the East Rand district, the Sharpeville congregation was one of the few still staunchly holding on to the uniforms when Pastor Mtsweni arrived in 1981 (Interview, Seritili 2008). Pastor Mtsweni was one of the three other ministers Mathole (Interview, 2008) and Tshabalala (Interview, 2008) mentioned to have played a significant role in the evangelicalisation of the Sharpeville congregation, namely: evangelists Reinhard Bonnke, Masusu Mofokeng and Ananias Ralekgolela.

Reinhard Bonnke conducted an evangelistic campaign in Sebokeng in 1979, and some members of the Sharpeville congregation who attended the campaign converted to 
evangelical Pentecostalism (Interview, Tshabalala 2008a, 17). ${ }^{7}$ Pastor Mtsweni found these few evangelical converts when he arrived in 1981. The first five years of his tenure accelerated evangelicalisation of the Sharpeville congregation through discontinuing tombstone unveiling services which used to be conducted on Sunday mornings. He insisted on the privatisation of the unveiling ceremony and mokete wa matshediso (literally: feast of condolences) by delinking the participation of the congregation. According to Mathole (Interview, 2008, 5), Pastor Mtsweni subjected some of these traditional practices to public ridicule, while showing a willingness to attend associated events to offer prayers privately. He used the same tactic concerning uniforms. He bargained with prayer women to excuse his wife from having to wear a uniform in exchange for their continued observance of the practice (Interview, Seritili 2008). On the other hand, according to Mathole (Interview, 2008), Pastor Mtsweni's sermons continued to undermine the beliefs around the practice. The practice of wearing a church uniform was finally defeated by evangelists Mofokeng and Ralekgolela.

Evangelists Masusu Mofokeng and Ananias Ralekgolela's evangelistic campaigns in Sharpeville, conducted between 1983 and 1985, led to some members of the AFM Sharpeville congregation burning their uniforms (Interview, Seritili 2008). Other members of the congregation, unhappy with the changes sweeping across the congregation, left to join Saint John Apostolic Faith Mission (St John AFM), Old Apostolic Faith Mission (Old AFM) and Bantu Apostolic Faith Mission (Bantu AFM) (Interviews: Mathole 2008, 5; Tshabalala 2008b, 21). Few others chose to abandon their affiliation with any church. Such was the case of Mr Letseleha, who, upon being introduced to the new pastor of his former congregation in 2000, accusingly said: "you have turned my church into one of these born-again churches" (Mofokeng 2018, ii). With these movements of members, the Sharpeville congregation remained with people who were open to the new form of Pentecostalism, thus assuming an evangelical Pentecostal identity unhindered.

\section{A Pastoral Account of Evangelicalisation of a Congregation}

The researcher would have regarded it as valuable to interview Pastor Paulus Mtsweni for his perspective on the evangelicalisation of the congregation in Sharpeville. However, he passed on before the researcher could interview him. In this section, the views and experiences of a minister who was sent to pastor a congregation that practised Zionist-like Pentecostalism, upon whom fell the arduous task of evangelicalising this congregation, will be reflected upon. His contribution, albeit not about Sharpeville AFM, is consistent with the question this article wants to answer. Further, it may provide clues to the reasons why the members of the AFM Sharpeville congregation (who

7 Tshabalala (Interview, 2008a, 17) dates Bonnke's revival to 1976. This was a memory fail, as there was no corroborating evidence. Therefore, Lebusa's $(2009,141) 1979$ date was chosen because of his younger age compared to Tshabalala — the ability to recall the date of the event favours him. 
resisted evangelicalisation) left and joined denominations that had seceded from the AFM.

Pastor Molefi Malete (Interview, 2008, 4-6) relates a story of reluctantly joining the AFM in 1979, after he was invited by Pastor Masusu Mofokeng and the Northern Free State district superintendent, Pastor Coertsen. These two had approached Pastor Malete because of his supposed success at planting a congregation and raising up 10 pastors in 10 years of ministry under the Assemblies of God in Viljoenskroon. He was about 35 years old when he was approached with an offer to take up the pastorate of one of the largest congregations of the AFM in the north-eastern Free State at the time. His reluctance was due to his perception of the black AFM as kereke ya seaparo (loosely translated as "a church that uses uniforms") and whose members were not born again. Pastor Malete (Interview, 2008, 3) had grown up in the Dutch Reformed Church in Africa and converted to evangelical Pentecostalism through Reverend Nicholas Bhengu's ministry in 1958. Pastor Malete (Interview, 2008, 8) characterises the AFM then as typically Zion-Apostolic, differing from other such churches only in its association with white people. His reluctance to join the AFM was only overcome one day when attending a national conference of this denomination as a driver for Pastor Masusu Mofokeng (Interview, Malete, 2008, 14). At the conference, he observed that the preaching was as evangelical as what he had heard under Nicholas Bhengu. Only then did Pastor Malete agree to take up the pastorate of the said congregation, although his tenure there confirmed his earlier observations that the black AFM was not born again - at least in the way he understood being born again. Significant to his experience as a pastor of a Zionist-like congregation, were the following themes which are discussed hereafter: African traditional orientation and practices, conservatism, the African sense of respect, and rejection of white cultural encroachment.

\section{African Traditional Orientation and Practices}

Beside their uniforms, Pastor Malete (Interview, 2008, 7) describes his first congregation in the AFM as people who practised polygamy, consulted diviners, held feasts of condolences and conducted ceremonies for unveilings of tombstones. The Sharpeville informants also allude to these practices. These practices fit the African traditionalist approach that Anderson $(2000,48-49 ; 2004,104)$ and other scholars ascribe to the older African-founded pneumatic churches. Anderson $(2000,49)$ argues that within the Zionist-Apostolic fraternity, there is ambivalence to most traditional practices. Mofokeng $(2018,115)$ adds that black Pentecostalism in the AFM was phenomenologically part of the Zionist universe until the 1970s. In his description of similar practices within the Ghanaian context, Larbi $(2002,148)$ argues that they are incompatible with evangelical Pentecostalism. Malete's (Interview, 2008, 7) earlier suspicions about the black AFM were confirmed by finding these abovementioned practices in the congregation he had come to pastor. 


\section{Conservatism}

Despite their African traditional practices, Pastor Malete's congregation jealously guarded what they believed to be the authentic tradition of the AFM about preaching. When he arrived, and they interviewed him, their interest was in the kind of gospel he subscribed to. They recognised the Bhengu and AFM types (Interview, Malete 2009, 25). Bhengu's gospel was akin to what the missionaries preached. The AFM's gospel, which they referred to as "the gospel of repentance and new birth," had some latitude to certain practices traditional to Africa such as polygamy, circumcision, umgidi-mokete ${ }^{8}$ (Interviews: Malete 2008, 7; Mathole 2008, 4). For the practitioners, these practices were congruent with Christian witness, albeit falling in the domain of family and not church (Interview, Mofokeng 2009, 19). Separation of these two domains was important, as its observance helped regulate the interaction between church and family traditions in favour of the latter. Therefore, in the question the board asked Pastor Malete, lay a concern to preserve what these members thought to be an AFM gospel, but was more a black AFM gospel, which was Zionist-like-an exercise in conservatism. This conservatism held African tradition and church teachings in tension for the benefit of the African Christian believer, who was to be protected from being overwhelmed by a gospel underpinned by Euro-American cultural values.

Nicholas Bhengu, whom Mathole $(2005,184)$ credits with being a "pioneer of evangelical Pentecostalism among black" people in southern Africa from as early as the 1940s, preached a gospel which, in the context of the AFM, contradicted and threatened the Zionist-like status quo among black AFM Pentecostals. Two of his converts, Pastors Richard Ngidi and Molefi Malete, related negatively to the Zionism extant in the AFM during the 1950s to 1970s. Their becoming members and ministers in this church took some convincing. Ngidi joined the AFM in obedience to a vision in which he saw its name emblazoned on the sky (Khathide 2010,43). Malete joined after being convicted by thoroughly evangelical preaching at a conference he only attended as a driver who chose to remain in the car because for him, the AFM was not a born again church (Interview, Malete 2008, 13). Bhengu's own words bear witness to his attitude towards a church like the AFM, which was known for the clapping of hands when singing, and its African followers, who were inclined towards the Old Testament, practised some traditional customs (Burger and Nel 2008, 246-251; Khathide 2010, 44; Mofokeng 2018, 61). Balcomb $(2005,341)$ quotes Bhengu saying: "We clap no hands or dance in the service of God. ... There are no traces of ... tribal or traditional customs in our great work. ... We base our faith and conduct on the teachings of the New Testament."

Bhengu's gospel fitted in well with the interest and missionary activity of EuroAmerican and white South African agents, who later gave impetus to evangelical Pentecostalism through parachurch ministries in high schools and universities across

8 Umgidi (Nguni) or mokete (Sotho) may be a celebratory or sombre gathering of family and community, linked to observance of African traditional culture. Meat and traditional brews, both alcoholic and non-alcoholic, form part of the food and drinks the attendees enjoy at such an event. 
the African continent (Anderson 2002, 170-171; Mathole 2005, 184). The revival following in the wake of this increased missionary activity, swept young people into old (AFM) congregations, resulting in a clash between the old "churchy" liturgical cultures and the youthful, tent-inspired worship styles dominated by English choruses, "amens," and musical instruments (Anderson 2002, 170; Interviews: Mofokeng 2009, 14; Seritili 2008). Therefore, members of the board of Pastor Malete's first charge in the AFM were relieved to hear that he preached the known gospel of new birth, which in their experience was traditional to the black AFM, and not Bhengu's gospel.

\section{African Sense of Respect}

According to Pastor Malete (Interview, 2008, 6), the Zionist-like Pentecostals of his first AFM congregation objected to the evangelical preachers' and converts' seeming disregard for traditional respect of seniors. The traditional sense of respect demands the use of mapata ("euphemisms") as substitutes for words perceived to be vulgar and actions deemed shameful. Accordingly, adults or seniors may not be reprimanded in the presence of their children or juniors. However, young evangelical preachers, eager to eradicate perceived sins, disregarded this protocol and were confrontational and disrespectful of elders in the presence of minors. This disrespectful tendency also accompanied testimonies by the repenting members - much to the chagrin of the rest. In the words of Togarasei $(2006,106)$, in his paper on modern Pentecostals, where he explains "modern" to be about embracing westernisation as one turns their back on African culture, the young evangelical preachers were being modern as they turned against the values of their elders. At Pastor Malete's congregation, the elders could not understand how those who claimed to be saved thought nothing of speaking vulgarities in the church. For any adult person to confess, in the presence of minors and in-laws, to having been an adulterer, or a drunkard, as many who claimed to be saved did, was counter-cultural (Interview, Malete 2008, 6). It appears that what Pastor Malete's congregation considered the AFM gospel, was a cultured approach to gospel preaching. Central to the concept of a "cultured approach to the gospel" is a tacit nod to (some) African traditional values and practices.

The existence of a cultured approach to the gospel need not mean that sin was condoned, as Khathide $(2010,44)$, commenting on the Zionist spirituality and its practices in the AFM of the 1950s in Natal, speaks highly of the faith and holiness of the Zionists within the AFM. Hwata $(2005,109-110)$ mentions the same when he describes what he refrains to label as Zionist spirituality in the AFM (in South Africa and Zimbabwe) before the 1970s — which Mofokeng $(2018,65)$ argues it was. Despite Hwata's (2005, 102) disapproving description of the Zionist spirituality in the denomination as emotional and suffering from "human infiltrations," he acknowledges the dedication, faith and holiness of its adherents (Hwata 2005, 109). Unsurprisingly, Masondo (2015, 239) describes the teachings and practices of St John AFM (a church started by Christinah Nku in 1939, from the AFM), as following Dowie's teachings of holiness seen in abstinence from alcohol, smoking, eating pork, sexual immorality, and so on. The mention of St John AFM here shows that, whether in the AFM or African 
Independent Churches, these Pentecostals observed holiness but from within an African worldview, despite some scholars and church leaders' reluctance to credit them as Christian.

\section{Rejection of White Religio-cultural Encroachment}

Pastor Malete (Interview, 2008, 16) relates being able to pacify his Zionist congregation by assuring them of his commitment to their perceived AFM gospel. He even pulled out the congregation from participating in the Paseka celebrations dominated by evangelicals for three years. Although he asked, and the board excused him from participation in the robing of members because he had cited the denomination's position on the matter, he indicated his willingness to have the practice continue (Interview, Malete 2009, 33). Even his wife became robed. Despite the above, there were pockets of resistance to his ministry because those members who were convicted by his preaching declared themselves saved and disparaged the uniforms and practices which others never saw as problematic. The resisting members labelled what was taking place sekgowa (white culture) and, believing that the church was under siege, intensified their resistance (Interview, Malete 2008, 7, 9). However, they lost the fight against evangelicalisation of the congregation and established a new church, Old AFM, under archbishop Nyembe of Vrede (Interview, Malete 2008, 8-9).

The formation of Old AFM was a protest against sekgowa, which the founders of this church deemed antithetical to black Pentecostal beliefs and practices that had characterised the AFM for decades. In forming the Old AFM, they joined other AFMderived denominations whose founders protested against the perceived encroachment of missionary-inspired evangelical culture and insensitivity to how black Pentecostals approached and expressed their spirituality-almost like Zionists in the African Independent Church movement (Interview, Mofokeng 2009, 22-23; Moripe 1994, 6367). Of these denominations, the following few serve as examples: Khobiso AFM (AFM-NC 1935), St Paul AFM, St Paul's Apostolic Faith Morning Star Church (Van Wyk 1988, 27-28) and Bantu (now Reformed) AFM (Moripe 1994, 96). St John AFM could be included in the above list, but there is no record of its founder, Mrs Christina $\mathrm{Nku}$, claiming to have started it in protest. However, its water-centred healing ministry and the era it was founded in (Masondo 2015, 233), together with the events in the AFM during that time, suggest that it too fits the description of churches whose founders were unhappy with culturally insensitive, missionary inspired and driven encroachments in the AFM.

The establishment of Khobiso AFM happened between the 1935 and 1936 Native Conferences, as its founder, Pastor James Molantoa, attended the 1935 conference. In his correspondence read at the 1936 Native Conference, he explained his departure from the AFM to be due to the constitutional changes he perceived as onerous on black people because they banned polygamy, the carrying of stick crosses, wearing of uniform, dancing around the sick, and circumcision (AFM-NC 1936). Archbishop Elias Ramoipone founded St Paul Apostolic Faith Morning Star Church in 1942 (Van Wyk 
1988, 28). The minutes of the 1935 Native Conference have an attendance record of one Elias Ramoipone listed under ministers and evangelists (AFM-NC 1935). The fact that the founder of St Paul Apostolic Faith Morning Star Church acknowledges his origin in, and membership of the AFM (Van Wyk 1988, 28), improves the conjecture that he was the same Elias Ramoipone mentioned in the 1935 conference minutes. Ramoipone explains his reason for leaving the AFM to have been due to the position taken against the use of water in healing the sick-which was his special gifting (Van Wyk 1988, 28). Moripe (1994, 57, 67), commenting on the 1945 secession which led to the formation of the Reformed AFM, also faults white domination and disregard of black culture in the AFM.

The abovementioned churches came to provide a home for AFM congregants who refused the evangelicalisation of their congregations, such as what happened in Sharpeville in the late 1970s and early 1980s (Interview, Mofokeng 2009, 20). The disgruntled members of the Sharpeville congregation scattered among the St John, Bantu and Old AFM churches in the area, thus leaving the evangelicals with no resistance anymore (Interviews: Mathole 2008, 5; Tshabalala 2008b, 20-21).

\section{Conclusion}

The aim of this article was to relate the thesis of evangelicalisation of black Pentecostalism to developments in a local congregation of the AFM. The specific question asked wanted to know how the evangelicalisation of black Pentecostalism happened at the congregational level of the AFM. The Sharpeville congregation, which now identifies as evangelical Pentecostal, fitted the criteria of a congregation that underwent evangelicalisation, as it was founded in the era dominated by Zionist-like Pentecostalism, which it had embraced. The abandonment of Zionist-like beliefs and practices, as well as the adoption of an evangelical identity, correlates with the arrival of an evangelical pastor. This is true in both the lay account from Sharpeville and the one given by Pastor Malete. In both these accounts, the pastor could decide what he wanted to be discontinued by a focused negative emphasis on such. He could also ask to be excused from the expectations of a Zionist-like congregation while allowing certain practices, which the new evangelical Pentecostalism either frowned upon or rejected, to continue. Generally, the pastor's evangelical preaching undermined the Zionist-like status quo through its framing of members as lacking salvation. With such a perspective, revivals and evangelistic campaigns, including conferences, presented conversion as a solution to this lack of salvation. Whereas the aim of revivals was to win those inside the congregation over to evangelicalism, evangelistic campaigns brought into the congregation new evangelical converts, mostly young, with no attachment to Zionist-like values or practices. For those already in the church, conversion signalled a willingness to be taken on a journey to recraft one's understanding of Pentecostalism away from the established Zionist-like form. As evangelicalisation was sanctioned by the hierarchy of the denomination-something that gave local players confidence - the failure of the Zionist Pentecostal conservatives 


\section{Mofokeng}

to prevent their own marginalisation and increasing defections to the evangelical camp, led to them leaving for other denominations that had seceded from the AFM earlier. Therefore, the congregation became uniform in its newly-found evangelical beliefs and practices.

\section{List of References}

AFM Bantu Executive Committee. 1962. Minutes of the Bantu Executive Committee. Auckland Park: AFM of SA, Archives.

AFM Bantu Executive Committee. 1971. Minutes of the Bantu Executive Committee. Auckland Park: AFM of SA, Archives.

AFM in Africa Executive Council. 1975a. Minutes of the 7th Executive Council Meeting. Auckland Park: AFM of SA, Archives.

AFM in Africa Executive Council. 1975b. Minutes of the 8th Executive Council Meeting. Auckland Park: AFM of SA, Archives.

AFM in Africa Executive Council. 1980. Minutes of the 26th Executive Council Meeting. Auckland Park: AFM of SA, Archives.

AFM Native Conference. 1915. Minutes of the General Native Workers Conference. Auckland Park: AFM of SA, Archives.

AFM Native Conference. 1923. Minutes of the General Native Workers Conference. Auckland Park: AFM of SA, Archives.

AFM Native Conference. 1929. Minutes of the General Native Workers Conference. Auckland Park: AFM of SA, Archives.

AFM Native Conference. 1930. Minutes of the General Native Workers Conference. Auckland Park: AFM of SA, Archives.

AFM Native Conference. 1935. Minutes of the General Native Workers Conference. Auckland Park: AFM of SA, Archives.

AFM Native Conference. 1936. Minutes of the General Native Workers Conference. Auckland Park: AFM of SA, Archives.

AFM Sharpeville Church Board. 20 May 1991. Letter to the Council. Sharpeville.

AFM Sharpeville Church Board. 1999. Request for Placement of Student Pastor Thabang Mofokeng. Sharpeville.

Anderson, A. 2000. Zion and Pentecost: The Spirituality and Experience of Pentecostal and Zionist/Apostolic Churches in South Africa. African Initiatives in Christian Mission. University of South Africa Press. 
Anderson, A. 2002. "The Newer Pentecostal and Charismatic Churches: The Shape of Future Christianity in Africa?" Pneuma 24 (2): 167-184. https://doi.org/10.1163/15700740260388027.

Anderson, A. 2004. Introduction to Pentecostalism. Cambridge: Cambridge University Press.

Anderson, A. 2006. "Exorcism and Conversion to African Pentecostalism." Exchange 35 (1): 116-133. https://doi.org/10.1163/157254306776066960.

Anderson, A., and S. Otwang. 1993. Tumelo: The Faith of African Pentecostals in South Africa. Pretoria: University of South Africa.

Balcomb, A. O. 2005. "Nicholas Bhengu: The Impact of an African Pentecostal on South African Society." Exchange 34 (4): 337-348. https://doi.org/10.1163/157254305774851475.

Bond, J. 1974. "Pentecostalism in the Pentecostal Churches." Journal of Theology for Southern Africa 1(1): 10-22.

Burger, I., and M. Nel. 2008. The Fire Falls in Africa: A History of the Apostolic Faith Mission of South Africa. Vereeniging: Christian Art Publishers.

Chaskalson, M. 1986. The Road to Sharpeville. Working Paper. Johannesburg: University of the Witwatersrand. Accessed April 2, 2019. http://wiredspace.wits.ac.za/handle/10539/8519.

Hatane, S. S. 2002. "Post-apartheid Desegregation in Vereeniging, 1991-1996." MA dissertation, Potchefstroom University of Christian Higher Education.

Hwata, B. 2005. "An Investigation of Different Phases of Pentecostal Experience in the Apostolic Faith Mission (AFM).” MTH dissertation, University of South Africa.

Jeffrey, I. 1991. "Cultural Trends and Community Formation in a South African Township: Sharpeville, 1943-1985.” MA dissertation, University of Witwatersrand.

Khathide, A. G. 2010. What a Giant of Faith: The Story of Richard Ngidi's Ministry of Miracles, 2nd edition. Kempton Park: Acad SA Publishing.

Larbi, K. 2002. “African Pentecostalism in the Context of Global Pentecostal Ecumenical Fraternity: Challenges and Opportunities.” Pneuma 24 (2): 138-166. https://doi.org/10.1163/15700740260388018.

Lebusa, G. M. 2009. “A Complementary Approach in Urban Mission: A Vaal Triangle Case Study." MA dissertation, North-West University.

Lodge T. G. 1984. "Insurrection in South Africa: The Pan-Africanis Congress and the Poqo Movement, 1959-1965.” Doctoral thesis, University of York. 
Masondo, S. 2015. "Prophets never Die? The Story of Bishop P.J. Masango of the St John's Apostolic Faith Mission.” Alternation Special Edition (14): 231-246.

Mathole, E. M. 2005. "The Christian Witness in the Context of Poverty: With Special Reference to South African Charismatic Evangelicals." Doctoral thesis, University of Pretoria.

Mofokeng, T. 2018. "Throwing the Baby out with the Bathwater: Cultural Reorientation of Black Pentecostalism in the Apostolic Faith Mission of South Africa (1940-1975)." MTH dissertation, University of South Africa.

Mofokeng, T., and M. Madise. 2019. "The Evangelicalisation of Black Pentecostalism in the AFM of SA (1940-1975): A Turning Point.” Studia Historiae Ecclesiasticae 45 (1):16. https://doi.org/10.25159/2412-4265/4050.

Moripe, S. 1994. "The Founding and Growth of the Reformed Apostolic Faith Mission of South Africa in its Historical Background." Theological Viatorum 21: 57-76.

Oelofse, M., and D du Bruyn. 2004. "The Importance of Oral History in a Transforming South Africa." Journal for Contemporary History 29 (1): 151-169.

Slabbert T. J. C. 2004. "An Investigation into the State of Affairs and Sustainability of the Emfuleni Economy." Doctoral thesis, University of Pretoria.

Steele, R. 1988. Reinhard Bonnke's vision: Plundering Hell to Populate Heaven. Melbourne, Florida: Dove Christian Books. Accessed September 26, 2019. https://archive.org/stream/DivineHealingGeneral34DivineHealingBooksInEpubFormat/Di vhealRbPlunderingHellToPopulateHeaven-RonSteele_djvu.txt.

Strydom, H. 2011. "Ethical Aspects of Research in the Social Sciences and Human Service Professions." In Research at Grassroots: For the Social and Human Service Professions, edited by A. S. de Vos, H. Strydom, C. B. Fouche, and C. S. L. Delport, 4th edition, 113130. Hatfield, Pretoria: Van Schaik Publishers.

Strydom, H., and C. S. L. Delport. 2011. "Sampling and Pilot Study in Qualitative Research." In Research at Grassroots: For the Social and Human Service Professions, edited by A. S. de Vos, H. Strydom, C. B. Fouche, and C. S. L. Delport, 4th edition, 390-396. Hatfield, Pretoria: Van Schaik Publishers.

Togarasei, L. 2006. "Cursed be the Past! Tradition and Modernity among (modern) Pentecostal(s) Charismatics.” Boleswa Occasional Papers in Theology and Religion 2006 (1): 109-118.

Vally N. T. 2010. “The 'Model Township' of Sharpeville: The Absence of Political Action and Organisation, 1960-1984.” MA dissertation, University of Witwatersrand. 


\section{Mofokeng}

Van Wyk, J. 1988. "St. Paul Apostolic Faith Morning Star Church of South Africa.” South African Journal of Ethnology 11 (1): 27-35.

\section{Interviews}

Malete, M. L. 2008. Interviewed by Thabang Mofokeng. 28 March, Vereeniging.

Malete, M. L. 2009. Interviewed by Thabang Mofokeng. 10 March, Vereeniging.

Mathole, E. 2008. Interviewed by Thabang Mofokeng. 4 July, Sharpeville.

Mofokeng, M. J. 2009. Interviewed by Thabang Mofokeng. 15 April, Phuthaditjhaba.

Seritili, I. M. 2008. Interviewed by Thabang Mofokeng. 1 June, Sharpeville.

Tshabalala, S. S. 2008a. Interviewed by Thabang Mofokeng. 29 April, Sharpeville.

Tshabalala, S. S. 2008b. Interviewed by Thabang Mofokeng. 24 June, Sharpeville. 